\title{
ФУНКЦИОНАЛЬНО-ОРИЕНТИРОВАННЫЙ СИНТЕЗ \\ ПРОТИВООПУХОЛЕВЫХ ГИБРИДНЫХ АГЕНТОВ НА ОСНОВЕ СТЕРОИДНОГО СКАФФОЛДА
}

\author{
В.А. Золотцев ${ }^{1,2}$, А.С. Латышева', А.М. Корольчук', Г.Е. Морозевич', \\ А.Р. Мехтиев', А.Ю. Мишарин' \\ ${ }^{1}$ Лаборатория Синтеза физиологически активных соединений, \\ ФГБНУ «Научно-исследовательский институт биомедицинской химии \\ им. В.Н. Ореховича», 119121, Россия, г. Москва, ул. Погодинская, д. 10, стр. 8. \\ ${ }^{2}$ Медицинский институт, ФГАОУ ВО «Российский университет дружбы народов», \\ 117198, Россия, г. Москва, ул. Миклухо-Маклая, д. 8.
}

DOI: 10.19163/MedChemRussia2021-2021-151

E-mail:vazolottsev@mail.ru

Стероиды широко представлены в животных и растениях в качестве регуляторов физиологических функций и обмена веществ, в связи с чем являются интереснейшим классом природных соединений с родственной структурой. Медицинская химия стероидов предлагает большое количество структур с широким спектром биологической активности. К сожалению, количество природных соединений ограничено, в то время как количество возможных их синтетических аналогов, гибридов и конъюгатов ограничено только воображением.

Цель данной работы был функционально-ориентированный синтез противоопухолевых гибридных агентов на основе стероидного скаффолда и изучение их биологической активности.

Мы разработали удобные схемы получения стероидных блоков из прегненолона и дегидроэпиандростерона на основе 17(20)Е-прегнена, 5,6-дегидроандростана, 5,6-дегидроандрост-16-ена и секо-D-андростана. Стероидные блоки превращали в целевые гибридные молекулы, содержащие в своем составе арильные и гетероциклические фрагменты. Разработанная схема позволяет получать гибриды с различными модификациями стероидного фрагмента; некоторые синтезированные соединения обладали значительной антиандрогенной активностью. С помощью компьютерного моделирования (докинг и молекулярная динамика) были построены трехмерные модели взаимодействия полученных соединений с активным центром CYP17A1 и лиганд-связывающим доменом андрогенового рецептора. Выявлено влияние структурных модификаций полученных соединений на ингибирование активности CYP17A1 и пролиферацию клеток карциномы простаты.

Работа выполнена в рамках «Программы фундаментальных научных исследований в Российской Федерации на долгосрочный период (2021-2030 годы)». 